\title{
Risk Factors of Gastrointestinal Stromal Tumor Recurrence
}

\section{Gastrointestinal Stromal Tümör Rekürrensinde Risk Faktörleri}

\begin{abstract}
Aim: Gastrointestinal stromal tumors (GIST) are the most common mesenchymal neoplasia of gastrointestinal system. Radical surgery with negative margin is the most important step for treatment of GIST. The primary aim of this study was to evaluate the risk factors for recurrence in patients who underwent surgery with diagnosis of GIST. Secondary aim was to reveal the factors that affect survival.

Materials and Methods: The data of 28 GIST patients who underwent surgery in our clinic between January 2013 and August 2019 were analyzed retrospectively. Patients preoperative radiological images, histopathological and immunohistochemical findings were noted.

Results: Eighteen patients were male, and ten patients were female. Median age was 64.5 (range; 50 87). Twenty-six patients (92.2\%) underwent open surgery and 2 patients (7.1\%) underwent laparoscopic surgery. Fifteen (53.6\%) of the 28 tumors were located in the stomach, 10 (35.7\%) in the small intestine, $2(7.1 \%)$ in the duodenum and 1 (3.6\%) was located multifocal. Mean tumor diameter was $10.1 \mathrm{~cm}$ (range; 0.5-21). The number of patients with recurrence was 5 (17.9\%). Tumor with necrosis, tumor located in an organ other than the stomach, and the high number of tumor mitosis revealed a significant difference for recurrence. In addition, large tumor size revealed significant statistical difference for recurrence. The median follow-up period was 26 (3-60) months. Necrosis of tumor and tumor type were the factors that significantly shortened survival.

Conclusion: In this study which we examined the GIST recurrence, it was observed that tumor size, tumor necrosis, increased number of mitosis and tumors located in an organ other than stomach are risk factors for recurrence. In this study which we examined GIST recurrence, tumor size, tumor necrosis, increased number of mitoses and tumors located in an organ other than the stomach are found to be risk factors for recurrence.

It was observed that the factors affecting the survival times, which are the secondary aim of the study, were cell type and tumor necrosis.
\end{abstract}

Keywords: Gastrointestinal stromal tumor; gastrointestinal system; mesenchymal cancer; surgery

\section{Öz}

Amaç: Gastrointestinal stromal tümörler (GIST), gastrointestinal sistemin en yaygın mezenkimal neoplazilerindendir. Temiz sınırlı cerrahi rezeksiyon GIST tedavisinin en önemli basamaklarından birini olușturmaktadır. Bu araștırmada primer amaç GIST tanısıyla ameliyat ettiğimiz hastalarda rekürrens için risk faktörlerini değerlendirmek, sekonder amaç ise hangi faktölerin sağkalıma etki ettiğini ortaya koymaktır. Gereç ve Yöntemler: Ocak 2013 ile Ağustos 2019 tarihleri arasında kliniğimizde cerrahi olarak tedavi edilen 28 GIST vakasının verileri retrospektif olarak incelendi. Hastalar operasyon öncesi görüntülemeler, histopatolojik ve immünohistokimyasal yönünden incelendi ve hasta bilgileri dokümante edildi.

Bulgular: Hastaların 18'i erkek, 10'u kadındı. Medyan yaș 64,5 idi. (en genç 50, en yașlı 87). Hastaların 26's $(\% 92,9)$ konvansiyonel, 2'si $(\% 7,1)$ laparoskopik yöntemle ameliyat edildi. Hastaların 15 'inde $(\% 53,6)$ lezyon midede, 10'ununda (\%35,7) jejenum-ileumda, 2'sinde (\%7,1) duodenumda, 1'inde $(\% 3,6)$ ise multifokalda yerleșimliydi. Ortalama tümör çapı 10,1cm idi (En uzun çap $21 \mathrm{~cm}$, en kısa çap 0,5 cm). Hastaların 27'sinde (\%96,4) DOG-1, 24'ünde (\%85,7) CD117, 23'ünde (\%82,1) CD-34, 9'unda (\%32,1) SMA, 3'ünde (\%10,7) Desmin, 2'sinde (\%7,1) S-100 pozitifliği izlenildi. Toplam rekürrens görülen hasta sayısı 5 idi (\%17,9). Yapılan istatistiksel analizler sonucunda tümörde nekroz olması, tümörün mide dıșında bir organda yerleșmiș olması ve tümör mitoz sayısının yüksek olması rekürrens için anlamlı istatistiksel fark ortaya çıkarmıștır. Ayrıca tümör boyutunun büyük olması rekürrens için anlamlı istatistiksel farklılık ortaya çıkarmıștır. Medyan takip süresi 26 (3-60) ay idi. Yapılan analizlerde tümörde nekroz görülmesi ve tümörün iğsi hücreli tipte olmas sağkalımı anlamlı ölçüde kısaltan etkenlerdi.

Sonuç: GIST rekürrensini incelediğimiz bu çalıșmada tümör boyutunun büyük olması, tümör nekrozu mitoz sayııının artmış olması ve tümörün mide dıșında bir organda yerleșmiş olması rekürrens için risk faktörü olduğu gözlemlenmiștir. Çalıșmanın sekonder amacı olan sağkalım sürelerini etkileyen faktörlerin ise hücre tipi ve tümör nekrozu olduğu görülmüștür.

Anahtar Sözcükler: Gastrointestinal stromal tümör; gastrointestinal sistem; mezenkimal kanser; cerrahi
Ozgur Ekinci', Metin Leblebici', Mehmet Acar', Cem Ilgin Erol', Orhan Alimoglu'

1 Istanbul Medeniyet University, Faculty of Medicine, Department of General Surgery

Received/Geliş : 14.07.2020 Accepted/Kabul: 24.11.2020

DOI: 10.21673/anadoluklin.755659

Corresponding author/Yazıșma yazarı Cem Ilgin Erol

Istanbul Medeniyet University, Goztepe Training and Research Hospital, General Surgery Clinic, Eğitim Mah. Dr. Erkin Cd. 34722 Kadikoy, Istanbul, Turkey E-mail: cemilginerol@gmail.com

\section{ORCID}

Özgür Ekinci: 0000-0002-2020-1913 Metin Leblebici: 0000-0002-1403-7643 Mehmet Acar: 0000-0002-6095-4522 Cem Ilgın Erol: 0000-0002-0955-9615 Orhan Alimoğlu: 0000-0003-2130-2529 


\section{INTRODUCTION}

Gastrointestinal stromal tumors (GIST) are the most common mesenchymal neoplasia of gastrointestinal system (1). GISTs develop from Cajal cells in the wall of the gastrointestinal tract (2). C-kit overexpression and platelet-induced growth factor alpha receptor (PDGFR Alpha) mutation have an important role in GIST pathogenesis (3). When the demographic distribution is analyzed, GISTs generally occurs in middleadvanced adults (2). GISTs are most commonly located in the stomach (60-70\%), small intestine (20-30\%), colon (10\%) and esophagus, respectively (4). Approximately $10-30 \%$ of GISTs have malignant potential (5). GISTs rarely cause lymph node or extra abdominal organ metastasis (6).

Eighty percent of primary GISTs occur with symptoms like hemorrhage, obstruction and gastric pain. About twenty percent of the patients are asymptomatic and diagnosing incidentally (7).

In the pre-treatment evaluation, upper gastrointestinal system endoscopy and abdominal CT can be used as the first option (8). Endoscopic biopsy may result negative because of the mass develops from the muscular layer of the stomach. EUS-guided or percutaneous techniques are recommended to obtain adequate biopsy materials $(8,9)$.

The first approach in GISTs treatment should be resection of the tumor with negative margin $(9,10)$. Avoiding rupture during resection is important to prevent intraabdominal spread (9). Enucleation is not recommended because recurrence of GIST occurs more frequently in patients who underwent enucleation (9). Tyrosine-kinase inhibitors are the first choice for treatment of inoperable locally advanced and/or metastatic disease (11). In the case of metastatic disease, surgery is not the first-line treatment alternative, but it can be performed in mandatory situations like bleeding and obstruction. Adjuvant therapy is recommended for high-risk patients after R0 surgical resection $(8,11)$.

Although the combination of R0 surgical resection and adjuvant therapy generally provides adequate cure, recurrence may occur in some patients. Recurrences are frequently observed locally, in the liver or on the peritoneal faces $(8,11,12)$. The primary aim of this study was to evaluate the risk factors for recurrence in patients who underwent surgery with diagnosis of GIST. Secondary aim was to reveal the factors that affect survival.

\section{MATERIALS AND METHODS}

The data of 28 GIST patients who underwent surgery in Istanbul Medeniyet University Goztepe Education and Research Hospital, General Surgery Clinic between January 2013 and August 2019 were analyzed retrospectively. This study was approved by Istanbul Medeniyet University Goztepe Training and Research Hospital Clinical Research Ethics Committee (Reference Number: 2019/0535). Wedge resection of the tumor with linear stapler was the surgical technique used in both open and laparoscopic surgeries. No additional procedures such as lymph node dissection or metastasectomy were performed. Each patient's age, gender, operation date, preoperative radiological findings, tumor resection margins, tumor size, histological type, mitosis count, growth pattern, necrosis, GIST risk group, imatinib therapy, CD117, DOG-1, CD34, SMA, S-100, Desmin, Ki-67 and survival data were recorded. The data were documented through our hospital system 'Nucleus'. Patients under 18 years old, with residual tumor and without follow-up data were excluded from the study. Recurrence was defined as local recurrence or metastasis during follow-up. All variables were analyzed statistically to be evaluated in terms of the relationship between recurrence or mortality. Variables were analyzed statistically, taking into account their number and proportional values, because some variables were too few in number. The data were analyzed by using IBM SPSS 23 . Categorical data were analyzed by chi-square and continuous data by $\mathrm{t}$-test. Survival data were analyzed by using the Kaplan-Meier method. The $\mathrm{p}$-value $<0,05$ was considered statistically significant.

\section{RESULTS}

A total of 28 patients met the inclusion criteria. İncludes patients demographic and histopathological examination data (Table 1). Eighteen patients were male and 10 were female. The median age was 64.5 (50-87). The median follow-up period was 26 (3-60) months. Twenty-six patients (92.2\%) underwent open surgery and 2 patients (7.1\%) underwent laparoscopic surgery. Fifteen $(53.6 \%)$ of the 28 tumors were located in the stomach, 10 (35.7\%) in the small intestine, $2(7.1 \%)$ in the duodenum and $1(3.6 \%)$ was located multifocal. Histopathological examination was re- 
Table 1. Patients demographic and histopathological examination data

\begin{tabular}{|c|c|}
\hline & Value \\
\hline \multicolumn{2}{|l|}{ Age(Median) } \\
\hline & $64.5(50-83)$ \\
\hline \multicolumn{2}{|l|}{ Gender } \\
\hline Male & $18(64.3 \%)$ \\
\hline Female & $10(35.7 \%)$ \\
\hline \multicolumn{2}{|l|}{ Tumor Location } \\
\hline Stomach & $15(53.6 \%)$ \\
\hline Ileum-Jejenum & $10(35.7 \%)$ \\
\hline Duodenum & $2(7.1 \%)$ \\
\hline Multifocal & $1(3.6 \%)$ \\
\hline \multicolumn{2}{|l|}{ Type of tumor } \\
\hline Spindle & $22(78.6 \%)$ \\
\hline Mixt & $5(17.9 \%)$ \\
\hline Epithelloid & $1(3.6 \%)$ \\
\hline \multicolumn{2}{|l|}{ Necrosis of tumor } \\
\hline Tumor with necrosis & $8(28.6 \%)$ \\
\hline Tumor without necrosis & $20(71.4 \%)$ \\
\hline \multicolumn{2}{|l|}{ Risk Group } \\
\hline 0 & $4(14.3 \%)$ \\
\hline 1 & $11(39.3 \%)$ \\
\hline 2 & $4(14.3 \%)$ \\
\hline 3 & $9(32.1 \%)$ \\
\hline \multicolumn{2}{|l|}{ CD117 } \\
\hline Positive & $24(85.7 \%)$ \\
\hline Negative & $4(14.3 \%)$ \\
\hline \multicolumn{2}{|l|}{ DOG1 } \\
\hline Positive & $27(96.4 \%)$ \\
\hline Negative & $1(3.6 \%)$ \\
\hline \multicolumn{2}{|l|}{ CD34 } \\
\hline Positive & $23(82.1 \%)$ \\
\hline Negative & $5(17.9 \%)$ \\
\hline \multicolumn{2}{|l|}{ SMA } \\
\hline Positive & $9(32.1 \%)$ \\
\hline Negative & $19(67.9 \%)$ \\
\hline \multicolumn{2}{|l|}{ S100 } \\
\hline Positive & $2(7.1 \%)$ \\
\hline Negative & $26(92.9 \%)$ \\
\hline \multicolumn{2}{|l|}{ Desmin } \\
\hline Positive & $3(10.7 \%)$ \\
\hline Negative & $25(89.3 \%)$ \\
\hline \multicolumn{2}{|l|}{ Resection Margin } \\
\hline Negative & $25(89.3 \%)$ \\
\hline Positive & $3(10.7 \%)$ \\
\hline
\end{tabular}

vealed to the resection materials, tumor types reported as 22 spindles cells (78.6\%), 5 mixed (17.9\%) and 1 epithelioid (3.6\%). Twenty-five (89.3\%) of the resected tumors had negative margins, 3 (10.7\%) of them had penetration of the tumor cells into the surrounding

\begin{tabular}{|ll|}
\hline \multicolumn{1}{|c|}{ Value } \\
\hline Growth Pattern & \\
Expansive & $25(89.3 \%)$ \\
Infiltrating & $3(10.7 \%)$ \\
Surgical Technique & \\
Open & $26(92.9 \%)$ \\
Laparoscopic & $2(7.1 \%)$ \\
Tyrosine Kinase Inhibitor Traetment & \\
Yes & $7(25 \%)$ \\
No & $21(75 \%)$ \\
\hline
\end{tabular}

tissue. Mean tumor diameter was $10.1 \mathrm{~cm}(0.5-21)$. Immunohistochemical examination revealed positive expression of DOG-1 in 27 (96.4\%), CD117 expression in 24 (85.7\%), CD-34 expression in 23 (82.1\%), SMA expression in 9 (32.1\%), Desmin expression in $3(10.7 \%)$ and S-100 expression in $2(7.1 \%)$ cases. The number of patients with recurrence was 5 (17.9\%). During post-operative follow-ups, metastasis occurred in $4(14.3 \%)$ cases and local recurrence occurred in 2 (7.1\%) cases. One of the patients had each of metastasis and local recurrence. The number of patients with recurrence was 5 (17.9\%).

In the statistical analysis for the recurrence development, which is the primary aim of the study, the analysis of the effect of categorical data on recurrence is presented (Table 2). Analysis of the effect of numerical data on recurrence is presented (Table 3 ). Non-gastric location of tumor $(\mathrm{p}=0.013)$ and tumor with necrosis $(\mathrm{p}=0.015)$ significantly increased recurrence. In the analysis of tumor diameter, the mean diameter of the tumor was $14.9 \mathrm{~cm}$ in patients with recurrence, and $7.8 \mathrm{~cm}$ in patients without recurrence. In the analysis of the effect of this data on recurrence, it was observed that the large tumor diameter increased recurrence $(\mathrm{p}=0.016)$. In addition, the increased number of tumor mitosis was found to significantly increased recurrence $(p=0.004)$. There were no significant findings effect on recurrence were analyzed.

To assess the secondary aim of the study, variables effect on survival was analyzed. During follow-up, a total of $6(21.4 \%)$ patients resulted in mortality. Estimated mean survival in all patients was 47.6 months (Figure 1). In the statistical analysis, patients with mixed type of tumor $(\mathrm{p}=0.04)$ or tumor with necrosis $(\mathrm{p}=0.03)$ had significant shortener survival. 
Table 2. Analysis of the effect of categorical data on recurrence

\begin{tabular}{|c|c|c|c|}
\hline & $\begin{array}{l}\text { Patients with } \\
\text { Recurrence }\end{array}$ & $\begin{array}{l}\text { Patients without } \\
\text { recurrence }\end{array}$ & $\mathbf{P}$ \\
\hline Gender & & & 0.601 \\
\hline Male & $3(16.7 \%)$ & $15(83.3 \%)$ & \\
\hline Female & $2(20.0 \%)$ & $8(80.0 \%)$ & \\
\hline Tumor Location & & & 0.013 \\
\hline Stomach & $0(0 \%)$ & $15(100 \%)$ & \\
\hline Other & $5(38.5 \%)$ & $8(61.5 \%)$ & \\
\hline Type of tumor & & & 0.285 \\
\hline Spindle & $3(13.6 \%)$ & $19(86.4 \%)$ & \\
\hline Other & $2(33.3 \%)$ & $4(66.7 \%)$ & \\
\hline Necrosis of tumor & & & 0.015 \\
\hline Tumor with necrosis & $4(50 \%)$ & $4(50 \%)$ & \\
\hline $\begin{array}{l}\text { Tumor without } \\
\text { necrosis }\end{array}$ & $1(5 \%)$ & $19(95.0 \%)$ & \\
\hline Risk Group & & & 0.066 \\
\hline 0 & $0(0 \%)$ & $4(100 \%)$ & \\
\hline 1 & $1(9.1 \%)$ & $10(90.9 \%)$ & \\
\hline 2 & $0(0 \%)$ & $4(100 \%)$ & \\
\hline 3 & $4(44.4 \%)$ & $5(55.6 \%)$ & \\
\hline CD117 & & & 0.617 \\
\hline Positive & $4(16.7 \%)$ & $20(82.3 \%)$ & \\
\hline Negative & $1(25.0 \%)$ & $3(75 \%)$ & \\
\hline DOG1 & & & 0.179 \\
\hline Positive & $4(14.8 \%)$ & $23(85.2 \%)$ & \\
\hline Negative & $1(100 \%)$ & $0(0 \%)$ & \\
\hline CD34 & & & 0.658 \\
\hline Positive & $4(17.5 \%)$ & $19(82.6 \%)$ & \\
\hline Negative & $1(20 \%)$ & $4(80 \%)$ & \\
\hline SMA & & & 0.527 \\
\hline Positive & $2(22.2 \%)$ & $7(77.8 \%)$ & \\
\hline Negative & $3(67.9 \%)$ & $16(32.1 \%)$ & \\
\hline S100 & & & 0.331 \\
\hline Positive & $1(50 \%)$ & $1(50 \%)$ & \\
\hline Negative & $4(15.4 \%)$ & $22(84.6 \%)$ & \\
\hline Desmin & & & 0.459 \\
\hline Positive & $1(33.3 \%)$ & $2(66.7 \%)$ & \\
\hline Negative & $4(16 \%)$ & $21(84 \%)$ & \\
\hline Resection Margin & & & 0.459 \\
\hline Negative & $4(16 \%)$ & $21(84 \%)$ & \\
\hline Positive & $1(33.3 \%)$ & $2(66.7 \%)$ & \\
\hline
\end{tabular}

\section{DISCUSSION}

GISTs are the most commonly operated mesenchymal tumors of the gastrointestinal system. Although stomach is the most common location site, GISTs may located in other organs too. Most of the GIST patients have benign clinical course but metastatic disease can

\begin{tabular}{|llll|}
\hline & $\begin{array}{l}\text { Patients with } \\
\text { recurrence }\end{array}$ & $\begin{array}{l}\text { Patients without } \\
\text { recurrence }\end{array}$ & $\mathbf{p}$ \\
\hline Growth Pattern & & & 0.073 \\
Expansive & $3(12.0 \%)$ & $22(88.0 \%)$ & \\
Infiltrating & $2(66.7 \%)$ & $1(33.0 \%)$ & \\
Surgical Technique & & & 0.669 \\
Open & $5(19.1 \%)$ & $21(80.8 \%)$ & \\
Laparoscopic & $0(0 \%)$ & $2(100 \%)$ & \\
Tyrosine Kinase & & & 0.281 \\
Inhibitor Traetment & & & \\
Yes & $0(0 \%)$ & $8(100 \%)$ & \\
No & $5(25 \%)$ & $15(75 \%)$ & \\
\hline
\end{tabular}

develop before or after surgical removal of the tumors. Aim of this study was to evaluate the risk factors for recurrence in patients who underwent surgery with diagnosis of GIST. Secondary aim was to reveal the factors that affect survival.

The National Cancer Institute (NIH) evaluated the risk factors in GIST recurrence and established a consensus by study of Fletcher et al. in 2002 (13). According to this study, tumor location, tumor size and the number of mitosis more than 50 were risk factors for tumor recurrence. In our study, it was observed that tumor location, size and number of mitosis increased recurrence.

In the GIST study conducted by De Matteo et al. with 200 patients in 2000 , there was a $30 \%$ recurrence rate at 2-year follow-up. Most common recurrence sites in this study were tumor resection area and liver (14). In our study, the recurrence rate was $17.9 \%$ and these recurrences were located in tumor resection area and liver. Despite the similarity of recurrence location, our recurrence rate is less than this study because treatment modalities have progressed in the past time.

A meta-analysis by Yi et al. on the effect of necrosis on GIST prognosis in 2019 included 18 studies with 2320 patients (15). This meta-analysis showed negative effect of necrosis on disease-free survival, survival without recurrence and overall survival. Our study also revealed significant relation between necrosis and recurrence but unlike the meta-analysis no relation between necrosis and survival was detected.

Seagles-Rojas et al. conducted a study to investigate the effect of Ki-67 index on GIST recurrence with 43 patients in 2018. In this study, Ki-67 had no effect on recurrence, but male gender and tumor size had ef- 
Table 3. Analysis of the effect of numerical data on recurrence

\begin{tabular}{|llll|}
\hline & $\begin{array}{l}\text { Average in patients with GIST } \\
\text { Recurrence (n=5) }\end{array}$ & $\begin{array}{l}\text { Average in Patients without GIST } \\
\text { recurrence (n=23) }\end{array}$ & $\mathbf{p}$ \\
\hline Age & $67.4 \pm 9.1$ & $66.1 \pm 10.8$ & 0.794 \\
Tumor Diameter (cm) & $14.9 \pm 3.4$ & $7.8 \pm 5.8$ & $\mathbf{0 . 0 1 6}$ \\
Ki67 index & 17.3 & 13.9 & 0.349 \\
Number of Mitosis (50 magnification) & 47 & 3 & $\mathbf{0 . 0 0 4}$ \\
\hline
\end{tabular}

fect on recurrence (16). Like this study we found that Ki-67 have no relation with recurrence. In addition, although we obtained results in parallel with this study in tumor size, we could not find a significant difference in gender.

In the study of Atak et al. the data of 21 GIST patients were evaluated retrospectively, the lesion was most frequently located in the stomach with $76.1 \%$, followed by the small intestine (17). In our study, the distribution of tumor location was similar, and tumor was most frequently located in stomach (53.4\%) and small intestine (35\%) respectively.

In a study conducted by Mazer et al. in 2019 to evaluate minimally invasive resection in 77 GIST patients, 53 (68\%) patients underwent laparoscopic resection. Postoperative hospital stay was shorter and complication rates were lower in laparoscopic resection. In ad-

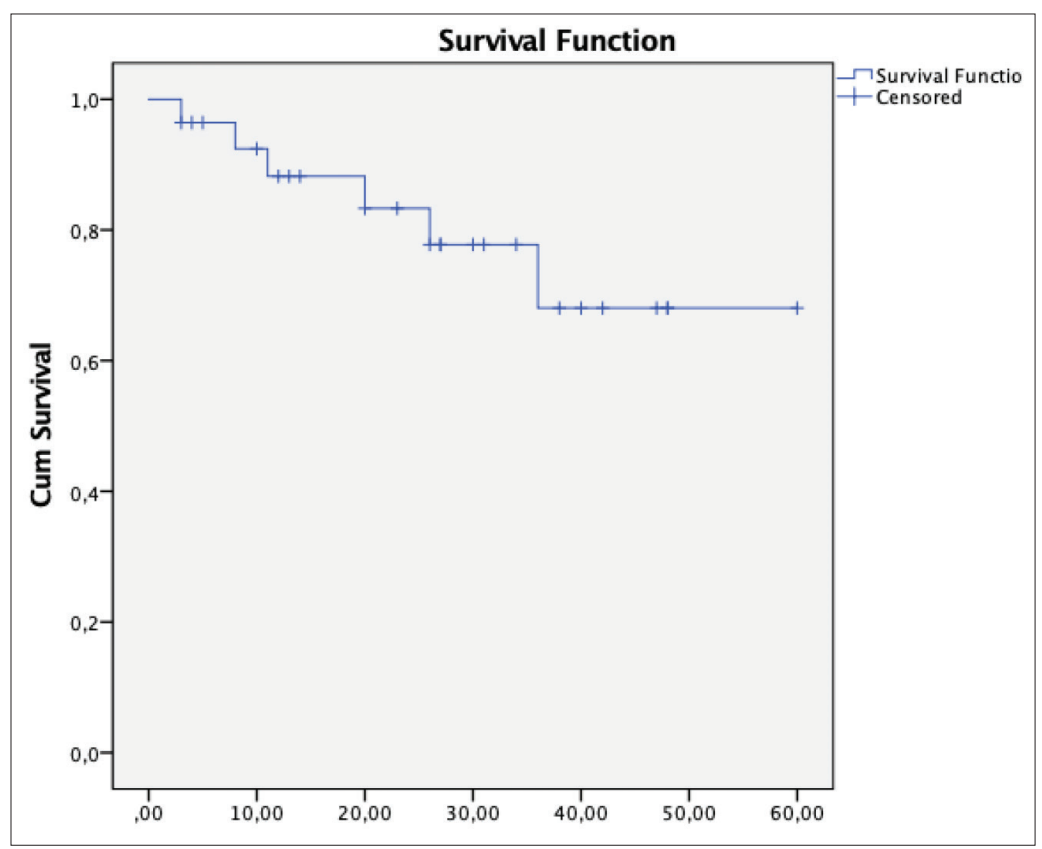

Figure 1. Total survival in all patients (Month) dition, there were 5 (6\%) patients with recurrence (18). In our study, 2 (7.1\%) patients underwent laparoscopic resection, and our recurrence rate was $18 \%$. Laparoscopy is proven to safe for GIST surgery, and it may be beneficial to increase minimally invasive resections and improve patient outcomes in eligible patients.

This study has some limitations. The sample size of the study, which is primarily a single-center retrospective study, is the most important limitation. In addition, the relatively short follow-up period prevents the long-term evaluation of survival, the secondary endpoint of the study.

\section{CONCLUSION}

In conclusion, we observed that tumor size, tumor necrosis, increased number of mitosis and tumors located in an organ other than stomach are risk factors for recurrence. It was observed that the factors affecting the survival times, which are the secondary aim of the study, were cell type and tumor necrosis. For expand the analysis of factors affecting survival, it will be appropriate to conduct studies with longer follow-up.

\section{Conflict of Interest and Financial Disclosure}

The authors declare that they have no conflict of interest to disclose. The authors also declare that they did not receive any financial support for the study. 


\section{REFERENCES}

1. Levy AD, Remotti HE, Thompson WM, Sobin LH, Miettinen M. Gastrointestinal stromal tumors: radiologic features with pathologic correlation. Radiographics. 2003;23:283-304.

2. Domansk HA, Walther CS. Gastrointestinal stromal tumor. Monogr Clin Cytol. 2017;22:89-91.

3. Caterino S, Lorenzon L, Petrucciani N, Iannicelli E, Pilozzi E, Romiti A, et al. Gastrointestinal stromal tumors: correlation between symptoms at presentation, tumor location and prognostic factors in 47 consecutive patients. World J Surg Oncol. 2011;9:13.

4. Miettinen M, Sarlomo-Rikala M, Lasota J. Gastrointestinal stromal tumors: recent advances in understanding of their biology. Hum Pathol. 1999;30:1213-20.

5. Akahoshi K, Oya M, Koga T, Shiratsuchi Y. Current clinical management of gastrointestinal stromal tumor. World J Gastroenterol. 2018;24(26):2806-17.

6. Nishida T, Blay JY, Hirota S, Kitagawa Y, Kang YK. The standard diagnosis, treatment, and follow-up of gastrointestinal stromal tumors based on guidelines. Gastric Cancer. 2016;19(1):3-14.

7. Lim KT, Tan KY. Current research and treatment for gastrointestinal stromal tumors. World J Gastroenterol. 2017;23(27):4856-66.

8. Landi B, Blay JY, Bonvalot S, Brasseurd M, Coindree JM, Emile JF, et al. Gastrointestinal stromal tumours (GISTs): French Intergroup Clinical Practice Guidelines for diagnosis, treatments and follow-up (Snfge, ffcd, gercor, unicancer, sfcd, sfed, sfro). Dig Liver Dis. 2019;51(9):1223-31.

9. Eriksson M, Reichardt P, Hall KS, Schütte J, Cameron S, Hohenberger $\mathrm{P}$, et al. Needle biopsy through the abdominal wall for the diagnosis of gastrointestinal stromal tumour - Does it increase the risk for tumour cell seeding and recurrence? Eur J Cancer. 2016;59:128-33.
10. Kim GH, Choi KD, Gong CS, Lee I, Park YS, Han M, et al. Comparison of the treatment outcomes of endoscopic and surgical resection of GI stromal tumors in the stomach: a propensity score-matched case-control study. Gastrointest Endosc. 2020;91(3):527-36.

11. Casali PG, Abecassis N, Aro HT, Bauer S, Biagini R, Bielack S, et al. Gastrointestinal stromal tumours: ESMOEURACAN Clinical Practice Guidelines for diagnosis, treatment and follow-up. Ann Oncol. 2018;29(Suppl 4):iv267.

12. Joensuu H, Vehtari A, Riihimäki J, Nishida T, Steigen $\mathrm{SE}$, Brabec $\mathrm{P}$, et al. Risk of recurrence of gastrointestinal stromal tumour after surgery: an analysis of pooled population-based cohorts. Lancet Oncol. 2012;13(3):265-74.

13. Fletcher CD, Berman JJ, Corless C, Christopher DM, Gorstein F, Lasota J, et al. Diagnosis of gastrointestinal stromal tumors: a consensus approach. Hum Pathol. 2002;33:459-65.

14. DeMatteo RP, Lewis JJ, Leung D, Mudan SS, Woodruff JM, Brennan MF, et al: Two hundred gastrointestinal stromal tumors: Recurrence patterns and prognostic factors for survival. Ann Surg. 2000;231:51-8.

15. Yi M, Xia L, Zhou Y, Wu X, Zhuang W, Chen Y, et al. Prognostic value of tumor necrosis in gastrointestinal stromal tumor. Medicine (Baltimore). 2019;98(17):e15338.

16. Segales-Rojas P, Lino-Silva LS, Aguilar-Cruz E, SalcedoHernández RA. Association of ki67 index with recurrence in gastrointestinal stromal tumors. J Gastrointest Cancer. 2018;49(4):543-47.

17. Atak T, Eren T, Burcu B, Sagiroglu J, Ozemir İA, Alimoglu O. Gastrointestinal stromal tumors: retrospective analysis of 21 cases. Haydarpasa Numune Med J. 2019;59(2):157-61.

18. Mazer L, Worth P, Visser B. Minimally invasive options for gastrointestinal stromal tumors of the stomach [published online ahead of print, 2020 Mar 27]. Surg Endosc. 